\title{
Elements of Child-Friendly Environment: The Effort to Provide an Anti-Violence Learning Environment
}

\section{Sigit Purnama}

\author{
Received: 20052016 / Accepted: 25052016 / Published online: 13122016 \\ ๑) 2016 Association of Indonesian Islamic Kindergarten Teachers Education Study Program
}

\begin{abstract}
Abstrad $T$ his article reported the important of child-friendly environment to reduce violence against children. A child-friendly environment is able to change an aggressive behavior to be a positive behaviour. In the opposite, an unfriendly environment, will increase the aggressive behavior in children. Both indoor and outdoor environment are as one of the circle dimension that are able to stimulate the early childhood development with a positive behaviour. The environment is constructed from some elements, such as line, shape and color. Each of them has psychological impression that varies and at once is able to affect the mental aspect of a child. With the effective elements, variation and its balance, will establish a child-friendly environment. The enviromnet that secure and comfortable that will be able to stimulate the early childhood development and also to reduce their aggressive behaviour.
\end{abstract}

Keywords elements, a child-friendly environment, violence.

\begin{abstract}
A bstrak Artikel ini memaparkan pentingnya lingkungan yang ramah untuk mengurangi perilaku kekerasan yang terjadi pada anak usia dini. Lingkungan yang ramah mampu mengubah perilaku agresif menjadi positif. Sebaliknya, lingkungan yang tidak ramah anak, justru akan meningkatkan perilaku agresif. Lingkungan indoor dan outdoor merupakan salah satu dimensi lingkungan yang dapat menstimuli perkembangan anak usia dini agar terbentuk perilaku positif. Lingkungan tersebut dibangun oleh beberapa elemen, seperti garis, bentuk, dan warna. M asing-masing elemen memiliki kesan psikologi yang bervariasi dan sekaligus dapat mempengaruhi psikologi anak. Penggunaan elemen-elemen yang tepat, bervariasi, dan seimbang akan membentuk lingkungan yang ramah anak, yakni lingkungan yang aman, nyaman, yang akan dapat menstimuli perkembangan dan mengurangi perilaku agresif anak usia dini.
\end{abstract}

Kata Kunci: elemen, lingkungan ramah anak, kekerasan.

\section{Pendahuluan}

Kekerasan merupakan salah satu persoalan yang berpengaruh terhadap praktik pendidikan anak usia dini. M orrison (2012: 47) mengungkapkan, "Kekerasan sepertinya telah menyebar di tengah masyarakat. Dari televisi sampai video games dan kekerasan domestik, anak-anak banyak melihat perilaku tidak baik." Data Komisi Perlindungan Anak Indonesia (KPAI) membuktikan hal itu. Berdasarkan data pengaduan yang diterima KPAI, hingga tahun 2015 tercatat sebanyal 127 anak menjadi korban kekerasan, 65 siswa menjadi pelaku kekerasan di sekolah, 71 anak menjadi 
korban tawuran, dan 88 anak menjadi pelaku tawuran. Pada sisi lain, fakta tersebut menimbulkan ketakutan bagi para orangtua, mereka khawatir anak-anaknya menjadi korban kekerasan (Susanto: 2016).

H ariandja (2015) melaporkan sebuah hasil riset yang menyatakan bahwa kekerasan sekolah di Indonesia tertinggi. Penelitian tersebut melibatkan lebih dari 9.000 anak sekolah berusia 12-17 tahun di lima negara dalam kurun waktu 2013-2014, dan khusus di Indonesia, sampel yang diambil berjumlah 1.738 murid sekolah berusia 12-14 tahun. Beberapa hasil penelitiannya menunjukkan bahwa kekerasan emosional merupakan bentuk kekerasan yang paling tinggi, disusul kekerasan fisik dan kekerasan seksual. Kekerasan itu terjadi di beberapa lokasi, yakni ruang kelas, taman bermain, sekitar gerbang sekolah, lobi sekolah, kantin, tempat parkir, ruang loker dan gudang, serta toilet.

M engapa kekerasan bisa terjadi pada anak usia dini? Bagaimana kekerasan itu bisa terjadi? Seperti apa kekerasan itu terjadi? Pertanyaan-pertanyaan tersebut merupakan sebagian pertanyaan yang muncul dan berpengaruh dalam perencanaan, pelaksanaan, dan evaluasi pendidikan anak usia dini. Hasil-hasil penelitian terdahulu menunjukkan bahwa anak-anak yang diasuh dan didik di lingkungan yang ramah, mereka akan dapat berkembang dengan optimal, sehat, berprestasi, mampu bekerjasama dengan teman lainnya, dan terhindar dari bentuk-bentuk kekerasan (Engineer, et.al: 2004; Rimm-Kaufman, et.al: 2004; Parsons: 2005).

Berdasarkan hasil-hasil penelitian tersebut, kekerasan terhadap anak itu dapat terjadi salah satunya karena kurangnya dukungan lingkungan yang baik. Dengan demikian, persoalan kekerasan terhadap anak ini mempengaruhi bagaimana guru dan pengelola lembaga pendidikan anak usia dini dalam merancang dan memberikan lingkungan belajar dan bermain yang bebas dari kekerasan, mengajarkan anak bergaul yang baik dengan teman-temannya, dan menjauhi kekerasan.

\section{Kekerasan terhadap anak}

Salah satu bentuk kekerasan terhadap anak-anak adalah intimidasi (bullying). Intimidasi adalah bagian dari agresi. Secara psikologis, agresi merupakan perasaan marah atau tindakan kasar akibat kekecewaan atau kegagalan dalam mencapai pemuasan atau tujuan yang dapat diarahkan kepada orang atau benda (kbbi.web.id). Ormrod (2008:125) mendefinisikan perilaku agresi (aggressive behavior) sebagai tindakan fisik atau psikologis yang secara sengaja dilakukan untuk menyakiti anak lain, seperti memukul, mendorong, berkelahi, mempermalukan, menghina, menyebarkan isu yang tidak benar atau mengucilkan. Berdasarkan rangkumannya terhadap hasil-hasil penelitian, ia menyebut ada dua bentuk agresi, yaitu agresi fisik (physical aggression) dan agresi relational (relational aggression). Agresi fisik adalah tindakan yang berpotensi menyebabkan tubuh cidera, umumnya terjadi pada anak laki-laki. Sedangkan agresi relasional merupakan tindakan yang dapat merenggangkan hubungan persahabatan dan hubungan interpersonal lainnya, umumnya terjadi pada anak-anak perempuan. 
A dapun intimidasi itu sendiri menurut Olweus terjadi manakala seorang anak berulang kali dan dari waktu ke waktu terkena tindakan negatif dari satu anak lain atau lebih (H orne dan Orpinas, 2003). Rolan (1989) mendefinisikan intimidasi sebagai kekerasan yang lama, baik fisik atau psikologis, yang dilakukan oleh individu atau kelompok, dan diarahkan kepada individu yang tidak mampu membela diri dalam situasi yang sebenarnya. Intimidasi berkaitan dengan kekerasan personal dan kekerasan di sekolah. Tindakan-tindakan intimidasi dapat berupa mengolok-olok, menampar, memukul, mendorong, menyakiti, mengambil barang pribadi, mengata-ngatai, mengucapkan perkataan yang tidak senonoh, dan menghina penampilan, perilaku, dan budaya. Pada jaman dahulu, tindakan-tidakan tersebut dianggap normal atau sebatas permainan anak-anak, namun saat ini tidak demikian halnya (M orrison, 2012: 49).

Menurut Griffin dan Gross (2004), intimidasi terhadap anak usia dini itu diperkirakan terjadi karena beberapa sebab, yaitu karena anak terlalu pasif atau provokatif, dan adanya gangguan internal dan eksternal. Anak berperilaku pasif dapat terjadi karena dalam pembelajaran, pendidik kurang mampu menciptakan suasana yang bisa mendorong semangat belajar, motivasi, minat, kreativitas, inisiatif, inspirasi, inovasi, dan kemandirian sesuai dengan karakteristik, minat, potensi, tingkat perkembangan, dan kebutuhan anak. Selain itu, dapat juga terjadi karena kurangnya dukungan lingkungan yang memadai, seperti kurangnya mainan dan benda-benda yang dapat dimainkan anak-anak, minimnya benda atau wadah yang dapat gunakan untuk aktivitas, tidak adanya mainan yang responsif, minimnya ruang berlantai yang aman dalam ruangan (indoor) atau daerah berumput di luar ruangan (outdoor).

Berdasarkan hasil-hasil penelitian terdahulu, Ormrod (2008: 126) menyebutkan bahwa perilaku agresif itu muncul dan dapat meningkat pada sebagian anak dan remaja oleh karena beberapa faktor, yaitu (1) faktor genetis (keturunan), (2) faktor lingkungan, (3) faktor neurologis, dan (4) faktor kognisi motivasi. Sifat agresif pada anak balita banyak dipengaruhi oleh faktor genetik, bahkan mencapai 50\% jika dibandingkan dengan faktor lingkungan. Sifat agresif ini biasanya muncul mulai dari masa bayi dan terus meningkat sampai pada usia antara 2 sampai 4 tahun. Balita yang memiliki gen agresif jika dibesarkan pada lingkungan keluarga yang kasar dan agresif maka sifat agresifnya akan semakin berkembang. Sebaliknya, jika dibesarkan pada keluarga yang penuh kedamaian dan kehalusan, maka sifat agresifnya dapat ditekan.

Faktor-faktor lingkungan juga turut berpengaruh terhadap perilaku agresif, seperti lingkungan rumah tangga yang disfungsional, tampilan kekerasan di lingkungan, tayangan kekerasan di media (televisi, gadget, internet). Teori ekologi yang dikemukakan Urie Bronfenbrenner setidaknya dapat memberikan penjelasan. Gambar 1 menjelaskan bahwa perkembangan anak-anak itu berada dalam konteks sistem hubungan yang membentuk lingkungan mereka.

Bronfenbrenner menyebut lima sistem lingkungan berlapis yang saling berkaitan, yaitu mikrosistem, mesosistem, eksosistem, makrosistem, dan kronosistem. Mikrosistem adalah lingkungan yang berkaitan dengan anak secara langsung, seperti keluarga, sekolah, kelompok sebaya, dan tetangga. Anak berperilaku dan bertindak mempengaruhi sistem ini dan juga 
dipengaruhi oleh sistem ini. M esosistem mencakup hubungan di antara mikrosistem. Sebagai contoh, ada tidaknya dukungan atau perhatian keluarga terhadap literasi akan mempengaruhi kinerja anak di sekolah. Sebaliknya, dukungan sekolah dan literasi keluarga akan mempengaruhi seberapa jauh keluarga akan menghargai pentingnya literasi.

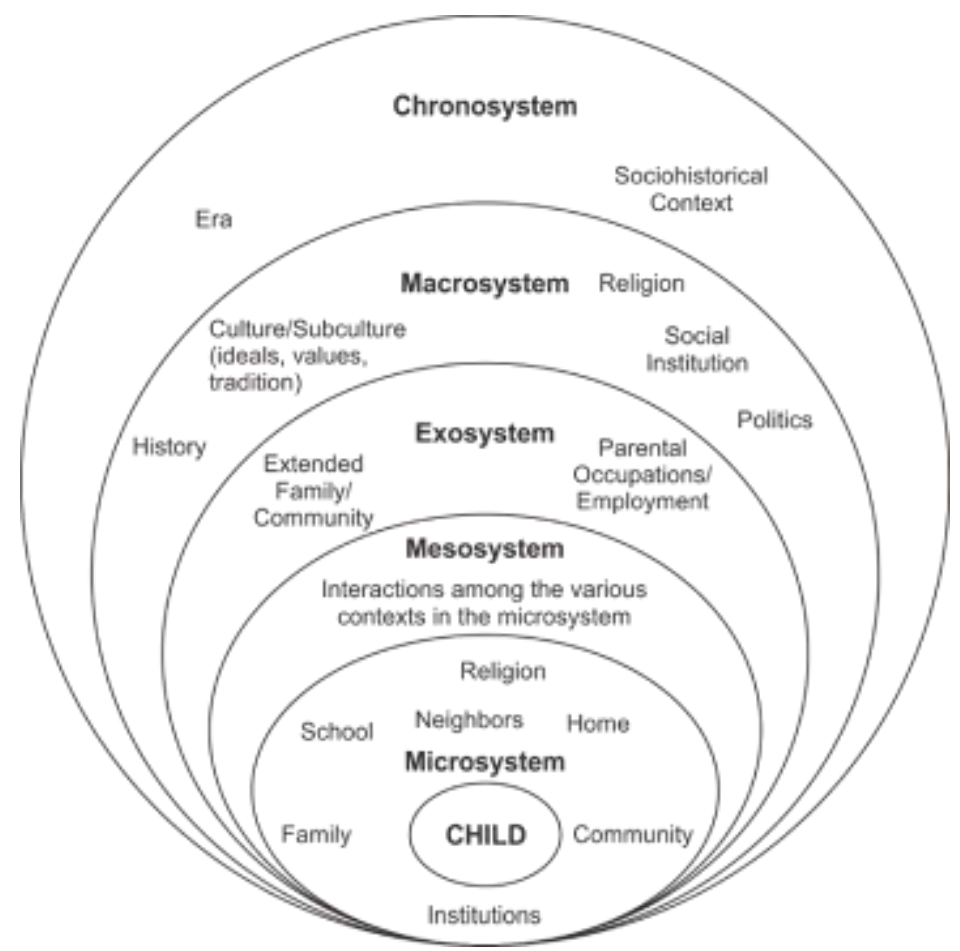

Gambar 1.

Teori Ekologi U rie Bronfenbrenner (Biddle, et.al, 2014: 102)

Ekosistem adalah sistem lingkungan yang berisi kejadian-kejadian yang tidak berinteraksi langsung dengan anak-anak, akan tetapi justru dapat mempengaruhi mereka. Contohnya seperti jam kerja orangtua yang bertambah (tidak berinteraksi dengan anak), sehingga akan mengurangi keterlibatan orangtua terhadap anak, dan pada akhirnya akan mempengaruhi perkembangan anak.

Makrosistem mencakup budaya, adat, dan nilai masyarakat secara umum. Contohnya seperti kekerasan sosial dan kekerasan yang ditampilan oleh media dapat mempengaruhi perkembangan. Anak-anak dapat menjadi lebih kasar, takut, atau khawatir karena meniru atau melihat tayangan kekerasan.

Kronosistem mencakup pengaruh lingkungan dari waktu ke waktu beserta caranya mempengaruhi perkembangan dan perilaku. Contohnya seperti perkembangan teknologi dengan produk-produk turunannya, seperti internet dan gadget, membuat anak-anak mahir, nyaman, dan terbiasa menggunakannya untuk pendidikan dan hiburan. Demikian halnya dengan maraknya fenomena wanita karir akibat industrialisasi, telah mengubah kehidupan keluarga. Perhatian ibu terhadap anak menjadi berkurang. 
Perilaku agresif anak juga ditunjukkan karena adanya gangguan otak atau sistem saraf pusat. Otak dapat terganggu oleh karena faktor makanan (Judarwanto: 2012). Perilaku yang tampak pada anak karena akibat gangguan ini adalah adanya gangguan konsentrasi, gangguan emosi, gangguan tidur, keterlambatan bicara, dan gangguan konsentrasi, yang terkadang membuat anak berperilaku agresif.

Faktor kognisi dan motivasi juga turut menyebabkan anak berperilaku agresif. Anak cenderung berperilaku agresif karena beberapa hal, yaitu (1) kurangnya empati terhadap anakanak yang menjadi korban kekerasannya; (2) tidak tahu bagaimana cara melakukan persuasi, negosiasi, atau kompromi, sehingga yang muncul adalah tindakan memukul, mendorong atau menyerobot; (3) adanya keyakinan bahwa kekerasan dan berbagai bentuk agresi merupakan cara yang tepat untuk menyelesaikan masalah; dan (4) adanya pandangan yang biasa bahwa perilaku yang ditunjukkan anak lain itu tampak sebagai tindakan memusuhi, padahal sesunggunya tidaklah demikian.

Berdasarkan uraian tersebut, tampak begitu kompleknya faktor-faktor yang menyebakan anak-anak berperilaku agresif. M eskipun demikian, perkembangan perilaku agresif dari masa anak usia dini ketahapan berikutnya lebih karena adanya faktor lingkungan, terutama lingkungan mikrosistem. Perilaku anak-anak akan berkembang ke arah negatif atau positif tergantung pada dukungan lingkungan yang diberikan. Dalam konteks lembaga pendidikan anak usia dini, terdapat elemen-elemen indoor maupun outdoor yang mampu menyediakan lingkungan yang mendukung terhadap perkembangan anak-anak ke arah positif. Dengan demikian, salah satu upaya yang dapat dilakukan untuk mengurangi perilaku kekerasan terhadap anak-anak adalah dengan menyediakan lingkungan yang aman, nyaman, dan mampu menstimuli aspek-aspek perkembangan anak usia dini.

\section{Lingkungan Ramah Anak}

Hasil penelitian Engineer, et.al (2004) menunjukkan bahwa anak yang dibesarkan, diasuh, dan dididik di lingkungan yang diperkaya lebih sehat, bahagia, dan berprestasi, dibandingkan dengan anak yang tidak dibesarkan di lingkungan yang diperkaya. Lingkungan yang diperkaya adalah lingkungan yang mengundang, nyaman, sehat, aman, mendukung, menantang, dan penuh penghargaan (Morrison, 2012: 204). Oleh karena itu, lingkungan anak seharusnya didesain sedemikian rupa sehingga memenuhi kriteria lingkungan yang diperkaya.

Berdasarkan hasil survey nasional terhadap anak dan remaja yang dilakukan secara longitudinal di Kanada, ditemukan bahwa anak usia pra-sekolah yang dibesarkan dengan sedikit pukulan, teriakan, atau ancaman di rumah, delapan tahun kemudian anak-anak itu menjadi remaja yang agresif, terlibat dalam perkelahian dan perilaku intimidasi di sekolah (Parsons, 2005: 4-5). H asil penelitian Rimm-Kaufman, et.al (2004) menyatakan bahwa kelas yang lingkungannya mendukung pembelajaran anak, akan mengurangi munculnya perilaku bermasalah, dan sebaliknya akan meningkatkan kerjasama anak dengan teman-temannya. 
Lingkungan berupa ruang-ruang yang responsif terhadap perkembangan anak usia dini, menurut Petersen \& Wittmer (2015: 55-58) setidaknya memiliki 6 (enam) dimensi, yaitu: (1) bersih, aman, bercahaya baik, berventilasi, dan pengaturan suhu yang sesuai, (2) penataan yang menciptakan suasana tenang, membuat anak-anak fokus satu sama lain, kepada guru, dan pada bahan-bahan yang dieksplorasi, (3) memiliki perabotan dan perlengkapan yang seukuran anakanak, (4) memiliki ruang yang nyaman, (5) memiliki beberapa lingkungan dalam ruang dan luar ruang yang memberikan pilihan kegiatan, bahan-bahan, dan mainan yang responsif terhadap perkembangan, minat, dan budaya anak-anak, dan (6) lingkungan yang mendukung orang dewasa untuk berinteraksi, mengawasi, dan mengobservasi anak-anak.

Berikut ini beberapa elemen yang dapat menciptakan lingkungan yang diperkaya atau lingkungan ramah anak. Lingkungan dimaksud mencakup indoor dan outdoor.

\section{Elemen Garis}

Garis merupakan unsur dasar seni, yang mengacu pada tanda menerus yang dibuat di sebuah permukaan. Dua titik pada bidang yang berbeda bila dihubungkan akan menjadi garis (W icaksono \& Trisnawati: 2014). Garis merupakan unsur elementer yang senantiasa muncul dan selalu mempunyai peran dalam menentukan bentuk-bentuk dari suatu bentuk. Dari segi ukuran, bentuk, dan gerak yang ditimbulkan, garis dapat berbentuk lurus, lengkung, patah-patah, bergelombang atau zig zag (lihat gambar 1 ). M asing-masing bentuk memiliki kesan bagi yang melihatnya. Tabel 1 menunjukkan macam-macam bentuk garis dan kesan yang dapat ditimbulkannya.

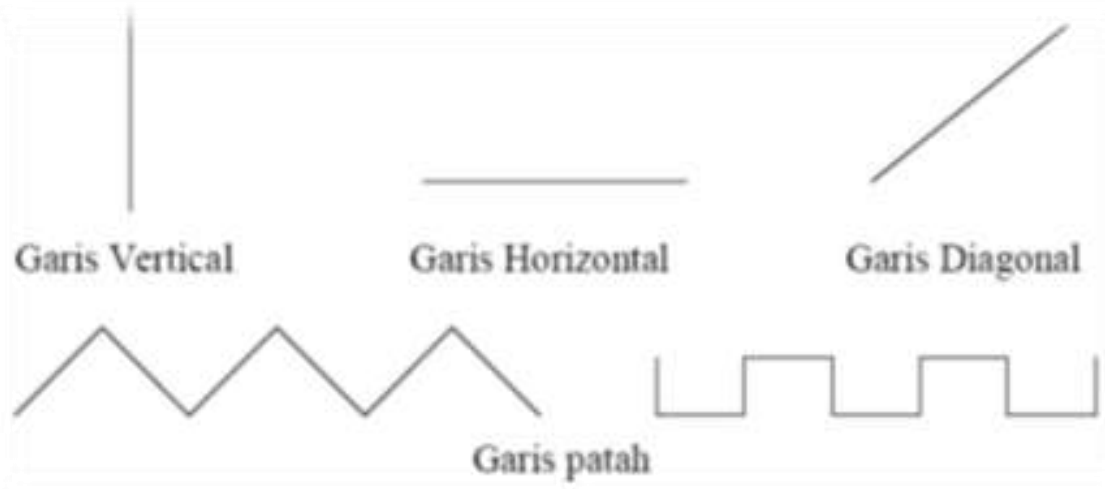

Gambar 1.

M acam-macam garis

Penggunaan elemen garis dalam mendesain lingkungan kegiatan anak usia dini perlu memperhatikan elemen ini. Elemen garis dapat digunakan untuk mendesain ruang, dinding, atap, lantai, bukaan (jendela, pintu, angin-angin), dan perabot ruangan. 
Tabel 1

M acam-macam garis dan kesan yang ditimbulkan

(W icaksono \& Trisnawati : 2015)

\begin{tabular}{cll}
\hline No & \multicolumn{1}{c}{ Klasifikasi Garis } & \multicolumn{1}{c}{ Kesan yang ditimbulkan } \\
\hline 1 & Garis tegak lurus & $\begin{array}{l}\text { meninggi, kuat, dan tegas, stabil, megah, tetapi } \\
\text { statis, kaku }\end{array}$ \\
\hline 2 & Garis mendatar & $\begin{array}{l}\text { rileks atau istirahat, ketenangan, kedamaian, } \\
\text { tenang, damai, tetapi pasif }\end{array}$ \\
\hline 3 & Garis menyilang & $\begin{array}{l}\text { penuh gerak atau dinamis, bergerak lari / } \\
\text { meluncur, dinamik, tetapi tampak tak seimbang. }\end{array}$ \\
\hline 4 & Garis lengkung & $\begin{array}{l}\text { keagungan dan kelembutan, ringan, dinamik, } \\
\text { dan kuat }\end{array}$ \\
\hline
\end{tabular}

Berdasarkan kesan-kesan yang dapat dimunculkan dari berbagai macam garis tersebut, dapat diketahui bahwa masing-masing garis memiliki kesan yang positif. Garis mendatar memiliki potensi besar untuk menciptakan lingkungan yang rilek, tenang, dan damai. Oleh karena itu, pemanfaatan elemen ini dalam mendesain lingkungan kegiatan anak usia dini, baik indoor maupun outdoor, dimungkinkan dapat mengurangi sifat agresif anak-anak. M eskipun demikian, penggunaan elemen ini tidak boleh berlebihan, karena berpotensi membuat anak-anak pasif. Desain lingkungan perlu dikombinasikan dengan elemen garis lain, seperti garis menyilang atau melengkung yang memiliki kesan dinamik, atau garis tegak lurus dengan kesan stabilnya.

Penggunaan elemen garis dalam lingkungan kegiatan anak usia dini dapat diwujudkan melalui pemasangan keramik lantai yang bervariasi, figura, dan portofolio anak di dinding kelas. Keramik dapat dipasang sedemikian rupa sehingga memunculkan garis mendatar, dan dipadukan dengan pemasangan keramik yang menciptakan garis melengkung. Figura dapat dipasang sedemikian rupa sehingga membentuk garis menyilang atau melengkung. Portofolio anak dapat dipasang sehingga membentuk garis mendatar.

U ntuk lingkungan luar kelas, implementasi elemen garis dapat diwujudkan melalui variasi berbagai jenis dan bentuk permainan, seperti permainan prosotan dan ayunan yang memiliki bentuk melengkung dan jungkit-jungkit membentuk garis lurus. Rumput tempat bermain anak juga dapat atur sedemikian rupa sehingga membentuk garis yang bervariatif.

\section{Elemen Bentuk}

Bentuk merupakan unsur seni yang memiliki sosok geometris tiga dimensi, seperti bola, kubus, silinder, dan kerucut (Wicaksono \& Trisnawati: 2015). M elalui bentuk itulah, anak-anak dapat menangkap dan memahami keberadaan sebuah benda melalui persepsi mereka.

Wicaksono \& Trisnawati (2015) menyebutkan tiga bentuk bidang primer, yaitu lingkaran, segitiga, dan bujur sangkar. Lingkaran adalah sederetan titik-titik yang di susun dengan jarak yang 
sama dan seimbang terhadap sebuah titik. Bentuk lingkaran memiliki sifat stabil dan dengan sendirinya menjadi pusat dari lingkungannya. Segitiga merupakan sebuah bidang datar yang dibatasi tiga sisi dan mempunyai tiga sudut. Sifat bentuk segitiga menunjukkan stabilitas. Bujur sangkar adalah sebuah bidang datar yang mempunyai empat sisi yang sama panjang dan empat sudut siku-siku $\left(90^{\circ}\right)$. Sifat bentuk bujur sangkar menunjukkan sesuatu yang murni dan rasional, oleh karena bentuknya statis, netral, dan tidak mempunyai arah tertentu.

Dalam lingkungan kegiatan anak usia dini, baik indoor maupun outdoor, terdapat berbagai bentuk yang mewujud dalam berbagai benda, seperti meja, kursi, ruang, halaman, rumput halaman, jendela, pintu, plafon, dan mainan. Perancangan dan penyediaan elemen bentuk lingkungan kegiatan yang monoton akan membuat labil dan distabilitas anak oleh karena sifat yang ditimbulkan oleh elemen tersebut.

Oleh karena itu, dalam merancang dan menyediakan lingkungan kegiatan anak usia dini, pengel ola lembaga seharusnya menyediakan elemen bentuk yang bervariasi. Sebagai contoh, meja dan kursi, hendaknya memiliki bentuk yang bervariasi seperti ada yang berbentuk lingkaran, segitiga, dan bujur sangkar. Jendela ruang dapat didesain sedemikian rupa, sehingga tidak monoton berbentuk bujur sangkar atau variasi dari bujur sangkar. Jendela dapat berbentuk lingkaran, atau bahkan segitiga. Pemasangan keramik lantai dapat dilakukan sedemikian rupa sehingga memiliki bentuk yang bervariasi. D emikian halnya dengan pemasangan plafon.

U ntuk lingkungan outdoor, misalnya dengan membuat halaman yang berbentuk lingkaran. Pemotongan rumput halaman yang bervariasi. Penyediakan permainan yang beragam dan memiliki bentuk yang bervariasi. Perancangan kolam renang anak yang memiliki bentuk kombinasi, tidak monoton berbentuk bujur sangkar. Demikian pula pemilihan dan pemasangan keramik kolam renang anak.

\section{Elemen Warna}

Purnama (2016) menyatakan bahwa warna merupakan elemen interior yang perlu diperhatikan ketika akan mendesain ruang kegiatan anak usia dini. M enurutnya, warna memiliki beberapa potensi, yaitu nilai keindahan, kesan dan pengaruh psikologis, dan efek untuk penyembuhan. Pemilihan warna yang memperhatikan tiga aspek tersebut dimungkinkan dapat menstimuli aspek-aspek perkembangan anak usia dini.

M enurut K riyoadi \& A nditya (Purnama, 2016), warna pada dasarnya memiliki kepribadian dan dapat mempengaruhi perasaan, lihat tabel 2 . Berdasarkan tabel 2, secara umum warna merah, ungu, kuning, hijau, biru, dan oranye dapat digunakan untuk merancang lingkungan (ruang) kegiatan anak usia dini, baik indoor maupun outdoor. Beberapa warna dapat dipilih atau dikombinasikan untuk memberikan warna pada dinding, lantai, kusen, meja, kursi, dan sebagainya. Sebagai contoh, warna kuning dan biru dapat menjadi pilihan warna dinding ruang, karena kesan keceriaan, menggerakkan, menyejukkan, dan menyenangkan yang ditimbulkannya. 


\section{Tabel 2.}

Kepribadian W arna

(Kriyoadi \& A nditya dalam Purnama, 2016)

\begin{tabular}{ll}
\hline JenisWarna & Kepribadian dan Pengaruh \\
\hline Merah & Penggugah semangat dan memberikan pengaruh yang kuat \\
\hline Ungu & $\begin{array}{l}\text { Melambangkan kemandirian dengan kesan mewah/ ambisi, } \\
\text { namun berkesan menyimpan misteri/spiritualitas }\end{array}$ \\
\hline Kuning & $\begin{array}{l}\text { Emosional yang menggerakkan energi dan menimbulkan } \\
\text { keceriaan }\end{array}$ \\
\hline Hijau & Menghadirkan keseimbangan dan perasaan yakin \\
\hline Biru & Menyejukkan dan menyenangkan \\
\hline Oranye & Hangat, mengundang energi, ketertarikan dan vital
\end{tabular}

M eskipun semua warna pada tabel 2 dapat dipilih dan digunakan, penggunaan warna merah dan ungu sebaiknya tidak digunakan secara berlebihan. Penggunaan warna merah yang berlebihan dimungkinkan dapat menimbulkan agresivitas anak, oleh karena kesan psikologis yang ditimbulkan. Demikian halnya warna ungu, yang memiliki kesan ambisius dan misteri.

\section{Simpulan}

Berdasarkan pemaparan tersebut di atas, dapat disimpulkan bahwa lingkungan kegiatan anak usia dini, baik indoor maupun outdoor dapat mempengaruhi prilaku anak. Lingkungan kegiatan yang ramah anak dapat menstimulasi perkembangan anak, dan pada sisi lain dapat mencegah atau mengurangi perilaku agresif anak usia dini. Lingkungan kegiatan ramah anak memiliki elemenelemen tertentu, seperti garis, bentuk, dan warna. Masing-masing elemen memiliki sifat dan kesan yang dapat mempengaruhi psikologi anak. Oleh karena itu, perancangan dan penyediaan lingkungan kegiatan hendaknya memperhatikan elemen-elemen tersebut. Pemilihan elemenelemen lingkungan yang tidak tepat (monoton) membuat anak kurang berkembang dengan baik, dan dimungkinkan dapat memunculkan perilaku agresif. 


\section{Daftar Pustaka}

Griffin, Rebecca S. dan Gross, A lan M . 2004. Childhood bullying: Current empirical findings and future directions for research. Aggression and Violent Behavior, 9 (4), p. 379-400. DOI: 10.1016/S1359-1789(03)00033-8.

Parsons, L. 2004. Bullied Teacher Bullied Student. Terjemahan Grace Worang. 2009. Jakarta: Grasindo.

Hariandja, R.Y. 2015. Tegas Hentikan Kekerasan Siswa. Diunduh pada 23 Desember 2016 dari http://mediaindonesia.com/news/read/1462/tegas-hentikan-kekerasan-siswa/2015-03-16.

Horne, A rthur M . dan Orpinas, P. 2003. Bullying, Childhood. Encyclopedia of Primary Prevention and Health Promotion. New York: Springer. hal. 233-240. DOI: 10.1007/978-1-4615-01954_33

Biddlw, Kimberly A.G., Garcia-N evarez, A., Henderson, Wanda J. R., dan Valero-Kerrick, A. 2014. Early Childhood Education: Becoming a Professional. London: Sage.

Morrison, George S. 2008. Fundamentals of Early Childhood Education. Terjemahan Suci Romadhona dan A pri Widiastuti. 2012. Jakarta: Indeks.

Rimm-Kaufman, S.E., La Paro, K.M ., Downer, J.T. dan Pianta, R.C. 2005. The Contribution of Classroom Setting and Quality of Instruction to Children's Behavior in Kindergarten Classrooms. The Elementary School Journal, 105 (4), hal. 377-394.

Petersen, Sandra H . dan W ittmer, D onna S. 2015. Kurikulum Pendidikan Anak U sia Dini Berbasis Pendekatan Antar Personal. Terjemahan A rif Rakhman. 2015. Jakarta: Kencana.

Purnama, Sigit. 2016. Warna-W arna Pilihan Interior Ruang Kegiatan Pengembangan A nak U sia Dini. JAPRA Jurnal Pendidikan Raudlatul Athfal Program Studi Pendidikan Guru Raudlatul Athfal Fakultas Tarbiyah dan Keguruan UIN Sunan Gunung Djati Bandung, 1 (1), hal. 1-15.

Susanto. 2016. 'Quo Vadis' Perlindungan Anak di Sekolah: Antara Norma dan Realita. Diunduh pada 30 A pril 2016 dari http://www.kpai.go.id/berita/kpai-quo-vadis-perlindungan-anakdi-sekolah-antara-norma-dan-realita/

Kamus Besar Bahasa Indonesia O nline/Daring (dalam jaringan), htpp://kbbi.web.id.

Ormrod, J. Ellis. 2008. Psikologi Pendidikan: M embantu Siswa Tumbuh dan Berkembang. Jilid 1. Terjemahan W ahyu Indianti, dkk. 2009. Jakarta: Erlangga.

Judarwanto, Widodo. 2012. Makanan Penyebab Gangguan Otak dan Perilaku pada Anak. Diunduh pada 16 M ei 2016 dari https://allergycliniconline.com/ 2012/10/01/makananpenyebab-gangguan-otak-dan-perilaku-pada-anak/).

Wicaksono, A ndie A. dan Tisnawati, Endah. 2014. Teori Interior. Jakarta: Griya Kreasi. 